\title{
Pelatihan Pembuatan Media Pembelajaran untuk Guru-Guru SMA di Cikarang
}

\author{
Rosalina $^{1)}$, Genta Sahuri ${ }^{2)}$, Tjong Wansen ${ }^{3)}$, Abdul Ghofir ${ }^{4)}$ \\ ${ }^{1)}$ Fakultas Komputer, Universitas Presiden, rosalina@president.ac.id \\ ${ }^{2)}$ Fakultas Komputer, Universitas Presiden, gentasahuri@president.ac.id \\ ${ }^{3)}$ Fakultas Komputer, Universitas Presiden, wansen@president.ac.id \\ ${ }^{4)}$ Fakultas Komputer, Universitas Presiden, geoff@president.ac.id
}

\begin{abstract}
ABSTRAK
Dalam era teknologi informasi saat ini, guru merupakan tenaga pendidik profesional yang perannya sebagai pemateri sudah bisa digantikan oleh teknologi. Menyikapi kondisi tersebut, para guru dituntut untuk bisa berfungsi sebagai fasilitator yang mampu mengembangkan kreativitas dan dinamika dalam menggali potensi sumber dan media pembelajaran. Dengan demikian perannya sebagai penyampai materi tetap diperlukan, yang pada akhirnya dapat tetap menjaga kualitas belajar mengajarnya. Untuk itu, guru dituntut untuk mampu menjadi fasilitator yang membekali dirinya dengan wawasan dan keterampilan dalam pengembangan dan pembuatan media pembelajaran yang mutakhir, yang sesuai dengan situasi dan perkembangan zaman. Berdasarkan diskusi dan interaksi yang dilakukan terlihat bahwa para guru di SMA daerah Cikarang pada umumnya masih mengalami kesulitan dalam beradaptasi dengan metode pembelajaran yang melibatkan media teknologi informasi. Oleh karena itu kegiatan ini dilaksanakan dengan harapan dapat meningkatkan efektivitas dan kualitas proses pembelajaran di SMA di wilayah Cikarang, Bekasi, Jawa Barat. Metode yang digunakan dalam pelatihan ini adalah ceramah, tanya jawab, dan praktik pembuatan media pembelajaran. Kegiatan ini dilaksanakan pada tanggal 13-14 November 2019 di Kampus Universitas Presiden. Setelah mengikuti kegiatan, para peserta memahami peran teknologi untuk menciptakan proses pembelajaran dan mendapatkan pengalaman baru dalam rangka menciptakan proses pembelajaran yang dinamis dan variatif.
\end{abstract}

Kata-kata Kunci: Pelatihan, Teknologi, Media Pembelajaran, Guru SMA.

\begin{abstract}
Teachers are trained educators in the modern age of information technology, whose function as presenters can be replaced with technology. In response to these conditions, teachers are required to be facilitators capable of developing creativity and dynamics in exploring learning resources and media potential. Thus the role as the material's conveyor is still needed, which in the end could still sustain the teaching and learning effectiveness. It is for this purpose that teachers need to be able to become facilitators who equip themselves with knowledge and skills in the creation of the new learning media that are relevant to the situation and creation of the times. This activity is therefore being conducted out in the hope of increasing the efficiency and effectiveness of the learning process in high schools in the Cikarang, Bekasi, West Java. The approach used in the course of this training is a lecture, question and response, and creating instructional media. This activity was carried out on November 13-14, 2019 at the President University Campus. After participating in the activity, the participants understood the role of technology to create a learning process and gain new experiences in order to create a dynamic and varied learning process.
\end{abstract}

Keywords: Training, Technology, Learning Medium, High School Teacher.

\section{PENDAHULUAN}

Pada prinsipnya, proses pembelajaran merupakan interaksi dan komunikasi yang melibatkan pendidik/pengajar dan siswa dan dilakukan secara dua arah, melalui dengan proses komunikasi berupa kegiatan mengirimkan pesan/materi dari guru kepada siswa 
maupun dari siswa kepada guru. Media yang digunakan oleh guru harus relevan dengan materi dan strategi yang digunakan guru dalam pembelajaran (Gunawan, 2016), maka yang menjadi poin utama adalah terkait penggunaan media yang tepat dan sesuai sehingga kegiatan belajar mengajar menjadi tepat sasaran dan terlaksana secara efektif dan efisien.

Beberapa penelitian telah mengklaim menemukan efek positif dari jejaring sosial terhadap hasil belajar siswa, termasuk didalamnya dalam performa akademik siswa. Efek tersebut diantaranya adalah meningkatkan pemikiran kritis, mengembangkan keterampilan berfikir dalam memecahkan masalah, meningkatkan kepuasan siswa, serta memperkuat proses pembelajaran aktif (Aljumah (2012), Venkatesh, Croteau, \& Rabah (2014), Goh, Quek, \& Lee (2010)).

Selain itu, Tang \& Lam (2014) juga menyebutkan bahwa blog dapat memotivasi pembelajaran siswa dan meningkatkan kepercayaan diri mereka dalam belajar. Menurut Tang \& Lam (2014), terdapat dua faktor utama yang berkontribusi terhadap efektivitas blog dalam meningkatkan pembelajaran yaitu partisipasi aktif dan kualitas interaksi yang tinggi serta komunikasi di antara siswa. Ketika kedua faktor ini dipertemukan, maka siswa akan dengan mudah mendapatkan manfaat dari penggunaan blog.

Situs jejaring sosial seperti Facebook, Blog dan Twitter menciptakan cara komunikasi baru untuk para guru dan siswa di lingkungan sekolah. Mengingat sudah banyaknya media aternatif yang tersedia saat ini, seperti penggunaan web blog (blog) yang gratis, maka para guru diharapkan bisa memanfaatkan secara optimal media tersebut. Hal ini bisa dilakukan untuk antisipasi terkait kekurangan waktu belajar secara tatap muka dan juga penghematan sumber daya yang biasanya digunakan (listrik, air, dll). Guru dapat membagikan materi melalui blog, baik berupa artikel, dokumen, gambar ataupun video. Selanjutnya siswa diberi tautan untuk setiap materi yang dapat diakses secara langsung dengan menggunakan jaringan internet.

Tidak hanya itu, blog juga bisa menjadi media interaksi dua arah yang memungkinkan tercipta diskusi dan komunikasi antara guru dan murid. Situs yang memberikan layanan untuk pembuatan blog diantaranya adalah Blogger.com dan Wordpress.com. Penggunaan salah satu dari layanan tersebut tidak memerlukan kemampuan teknis terkait bahasa pemrograman ataupun database, sehingga tidak ada kendala bagi guru atau murid dengan disiplin selain IImu Komputer atau Teknik Informatika. Layanan tersebut tidak hanya bisa diakses melalui media komputer atau laptop, namun juga bisa dari smartphone berbasis android atau IOS.

Namun belum banyak guru-guru SMA di wilayah Cikarang yang memanfaatkan media pembelajaran untuk mendukung proses belajar mengajar. Alasannya antara lain adalah adanya keterbatasan waktu dalam mempersiapkan media pembelajaran, 
keterbatasan

dana, dan pengetahuan dalam penggunaan teknologi untuk mendukung proses pembelajaran.

Adapun tujuan dari diadakannya kegiatan pengabdian pada masyarakat adalah untuk mengenalkan serta mensosialisasikan penggunaan media pembelajaran berbasis online dengan aplikasi andorid dalam proses kegiatan belajar mengajar di kelas kepada guru-guru SMA anggota Musyawarah Guru Mata Pelajaran (MGMP) Teknik Informatika dan Komputer (TIK) Kabupaten Bekasi, yang berada di wilayah Cikarang, Bekasi, Jawa Barat.

\section{METODE PELAKSANAAN}

Para guru yang memiliki latar belakang disiplin ilmu yang berbeda tentunya perlu persiapan untuk proses kegiatan pengembangan media berbasis android yang dilakukan secara online ini. Untuk itu, kepada mereka para guru yang tergabung dalam MGMP TIK di Kabupaten Bekasi perlu diberi keterampilan untuk mempersiapkan materi serta mampu merancang proses pembelajaran melalui media berbasis aplikasi android online dengan menggunakan blog.

Kerangka kegiatan disajikan pada Gambar 1. Kegiatan pelatihan diselenggarakan dengan metode ceramah, tanya jawab, dan praktik, dengan penjelasan sebagai berikut:

1. Ceramah dan Tanya Jawab

Metode ini bertujuan untuk menyampaikan rangkaian teori tentang pengertian dan perkembangan media pembelajaran

2. Praktik

Pada sesi ini, peserta pelatihan akan dibimbing dalam menyiapkan dan meyusun proses pengembangan media berbasis aplikasi. 


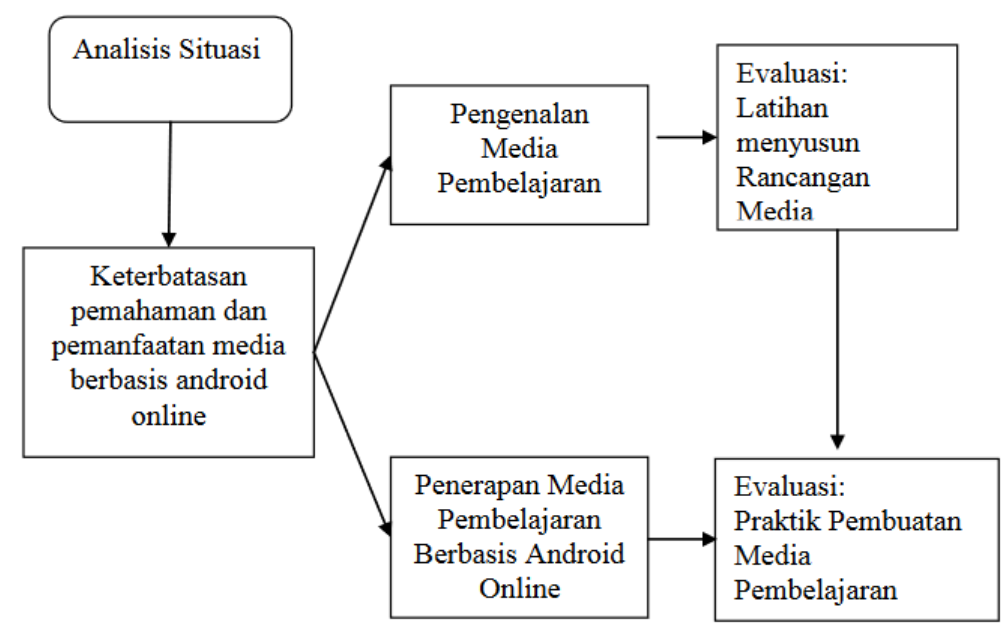

Gambar 1.

Realisasi Pemecahan Masalah

Sasaran kegiatan ini adalah para guru-guru MGMP TIK Kabupaten Bekasi. Berikut diberikan poin-poin evaluasi pencapaian target dari kegiatan terlihat pada Gambar 2.

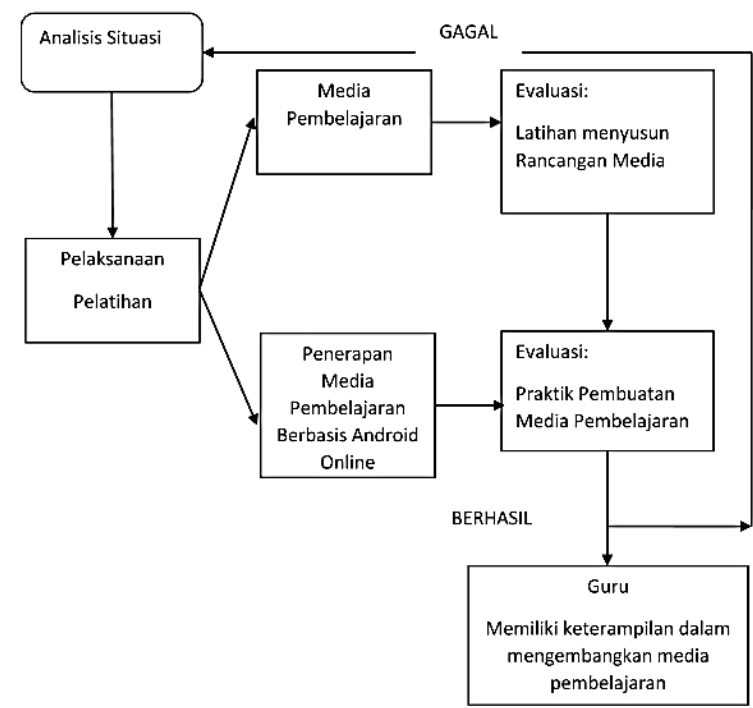

Gambar 2.

Evaluasi Pencapaian Target Kegiatan

Kegiatan ini dilaksanakan di Ruang Laboratorium Komputer Universitas Presiden di Lantai 2 Gedung A, dengan jadwal pelatihan hari pertama terlihat pada Tabel 1 dan jadwal pelatihan pada hari kedua terlihat pada Tabel 2.

Tabel 1.

Jadwal Pelatihan Hari Pertama 


\begin{tabular}{|c|c|c|c|}
\hline Jam & Kegiatan & Penanggung Jawab & $\begin{array}{c}\text { Jumlah Jam } \\
\text { Pelaksanaan }\end{array}$ \\
\hline $12: 30-12: 45$ & Registrasi Peserta & Tim Pelaksana & \\
\hline $12: 45-15: 00$ & $\begin{array}{c}\text { Pembukaan dan } \\
\text { Penyampaian Materi } \\
\text { - Pengertian Media } \\
\text { Pembelajaran } \\
\text { - } \text { Peran dan } \\
\text { Fungsi Media } \\
\text { - } \text { Taksonomi } \\
\text { Media } \\
\text { Pembelajaran } \\
\text { - } \text { Karakteristik } \\
\text { Media } \\
\text { Pembelajaran }\end{array}$ & Rosalina & 2 Jam 15 Menit \\
\hline $15: 00-15: 15$ & ISHOMA & & \\
\hline 15:15-17:00 & $\begin{array}{l}\text { Penyampaian Materi: } \\
\text { Pengembangan } \quad \text { dan } \\
\text { Evaluasi } \\
\text { Pembelajaran }\end{array}$ & Abdul Ghofir & 1 Jam 45 Menit \\
\hline $17: 00-17: 10$ & Penutup & Tim Pelaksana & \\
\hline \multicolumn{3}{|c|}{$\begin{array}{lll} & \text { Total }\end{array}$} & $4 \mathrm{Jam}$ \\
\hline
\end{tabular}

Pada Tabel 1 terlihat bahwa kegiatan diawali dengan registrasi ulang para peserta pelatihan yang dimulai pada jam 12:30, kemudian dilanjutkan dengan pembukaan oleh ketua tim pelaksana yaitu Ibu Rosalina, M.Kom. Setelah pembukaan, kegiatan dilanjutkan dengan penyampaian materi mengenai media pembelajaran, peran serta fungsi media pembelajaran serta karakteristik media pembelajaran. Jam 15:00 kegiatan diberhentikan untuk sementara dan kegiatan diisi dengan istirahat, sholat dan makan siang (ishoma) dengan durasi 15 menit. Setelah ishoma dilanjutkan dengan penyampaian materi oleh Bapak Abdul Ghofir, S.Kom., M.Kom. tentang evaluasi dan pengembangan media pembelajaran untuk mendukung proses belajar mengajar dikelas.

Pada Tabel 2 terlihat rincian jadwal kegiatan pada hari kedua, yang lebih ditekankan pada praktek pembuatan media pembelajaran dengan menggunakan Wordpress dan pembuatan media pembelajaran berbasis android.

Tabel 2.

Jadwal Pelatihan Hari Kedua 


\begin{tabular}{|l|l|l|l|}
\hline Jam & Kegiatan & Penanggung Jawab & $\begin{array}{l}\text { Jumlah } \\
\text { Pelaksanaan }\end{array}$ \\
\hline $12: 30-12: 45$ & Registrasi Peserta & Tim Pelaksana & \\
\hline $12: 45-15: 00$ & $\begin{array}{l}\text { Penyampaian Materi: } \\
\text { Praktik Pembuatan } \\
\text { Blog Word Press }\end{array}$ & Genta Sahuri & 2 Jam 15 Menit \\
\hline $15: 00-15: 15$ & ISHOMA & & 1 Jam 45 Menit \\
\hline $15: 15-17: 00$ & $\begin{array}{l}\text { Penyampaian Materi : } \\
\text { Praktik Pembuatan } \\
\text { Aplikasi } \\
\text { Berbasis Android }\end{array}$ & Tjong Wansen & \\
\hline $17: 00-17: 10$ & Penutup & Tim Pelaksana & Total Jam \\
\hline
\end{tabular}

\section{HASIL DAN PEMBAHASAN}

Peserta yang hadir pada setiap pertemuan adalah 15 orang guru. Pengabdian pada masyarakat dilaksanakan selama 2 hari pada tanggal 13 dan 14 Novemer 2019, dengan jumlah jam pelaksanaan tiap harinya adalah 4 jam pelaksanaan dan total jam pelaksanaan selama 2 hari adalah 8 jam.

Proses kegiatan yang dilakukan dari awal sampai akhir berjalan dengan sangat baik. Bisa dilihat dari peserta yang selalu hadir dalam setiap sesi. Para peserta sangat antusias dalam mengikuti kegiatan ini, sebab kegiatan ini tidak hanya berupa penyampaian materi tatap muka, namun juga membuat blog dengan menggunakan aplikasi Wordpress beserta pembuatan media berbasis android. Kegiatan tersebut sangat berpengaruh terhadap peserta yang notabene adalah pendidik di tingkat sekolah menengah atas dalam hal mereka memberikan materi pelajaran secara online di lingkungan sekolah. Keseriusan peserta terlihat dari banyaknya mereka yang mengajukan pertanyaan kepada tim pengabdi terkait materi-materi yang diberikan. Peserta memahami bahwa kegiatan ini merupakan sarana pengenalan sekaligus pembelajaran untuk pembuatan blog pada Wordpress dan pembuatan media berbasis android.

Berdasarkan hasil evaluasi pelaksanaan pelatihan yang diberikan kepada peserta kegiatan pada akhir acara kegiatan diketahui bahwa sebanyak 95\% peserta menilai pemateri menyampaikan materi dengan sangat baik dan $5 \%$ menilai bahwa pemateri menyampaikan materi dengan baik, sebagaimana terlihat pada Gambar 3. 


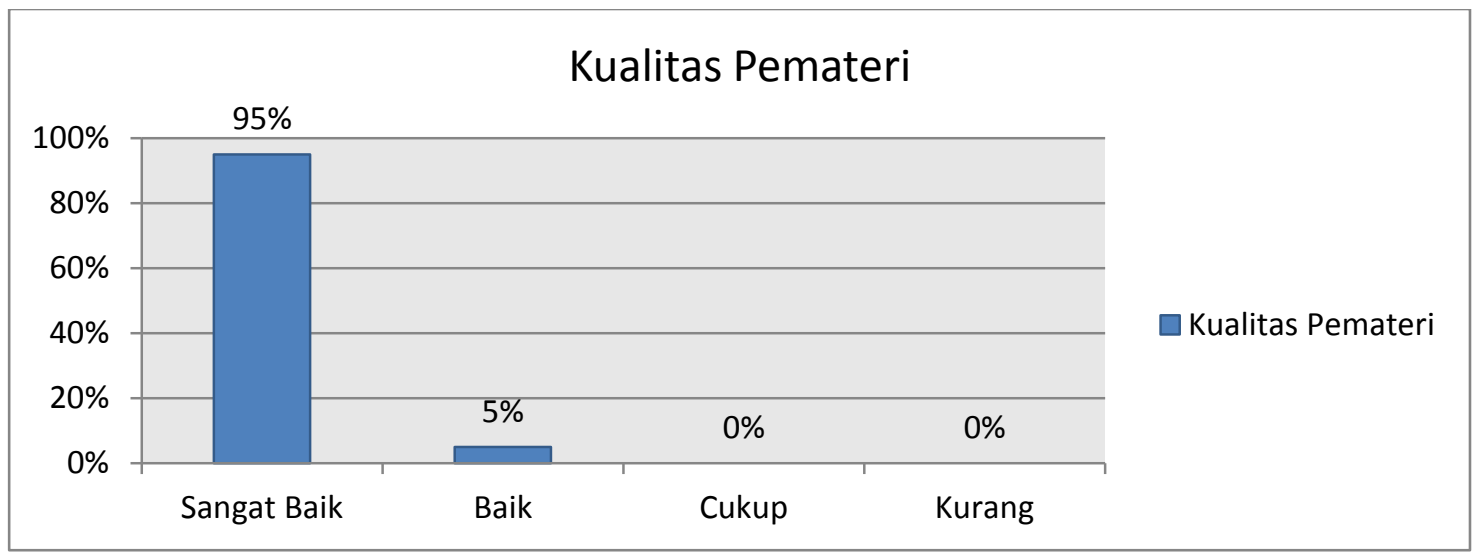

Gambar 3.

Evaluasi terhadap Kualitas Pemateri

Terkait kualitas modul, 95\% peserta menilai modul pelatihan yang digunakan sangat baik, $3 \%$ peserta menilai baik, dan $2 \%$ menilai modul yang diberikan cukup baik, sebagaimana terlihat pada Gambar 4.

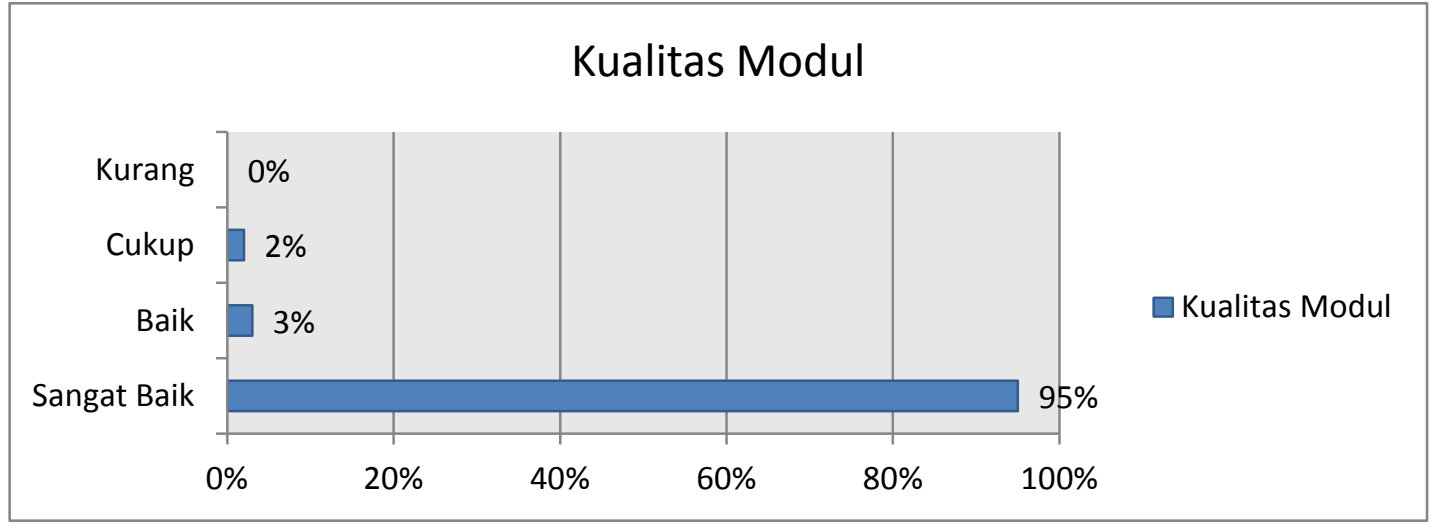

Gambar 4

Evaluasi terhadap Kualitas Modul Pelatihan

Adapun evaluasi terhadap tingkat pemahaman peserta, terlihat pada Gambar 5, sebanyak $90 \%$ peserta sangat paham dengan materi yang diberikan, $7 \%$ peserta paham, dan $3 \%$ peserta cukup paham. Tingkat pemahaman tidak mencapai $100 \%$ karena durasi waktu pelatihan dirasakan kurang mencukupi. Alasan lain adalah para peserta tidak seluruhnya memiliki pengetahuan tentang basic coding di android. 


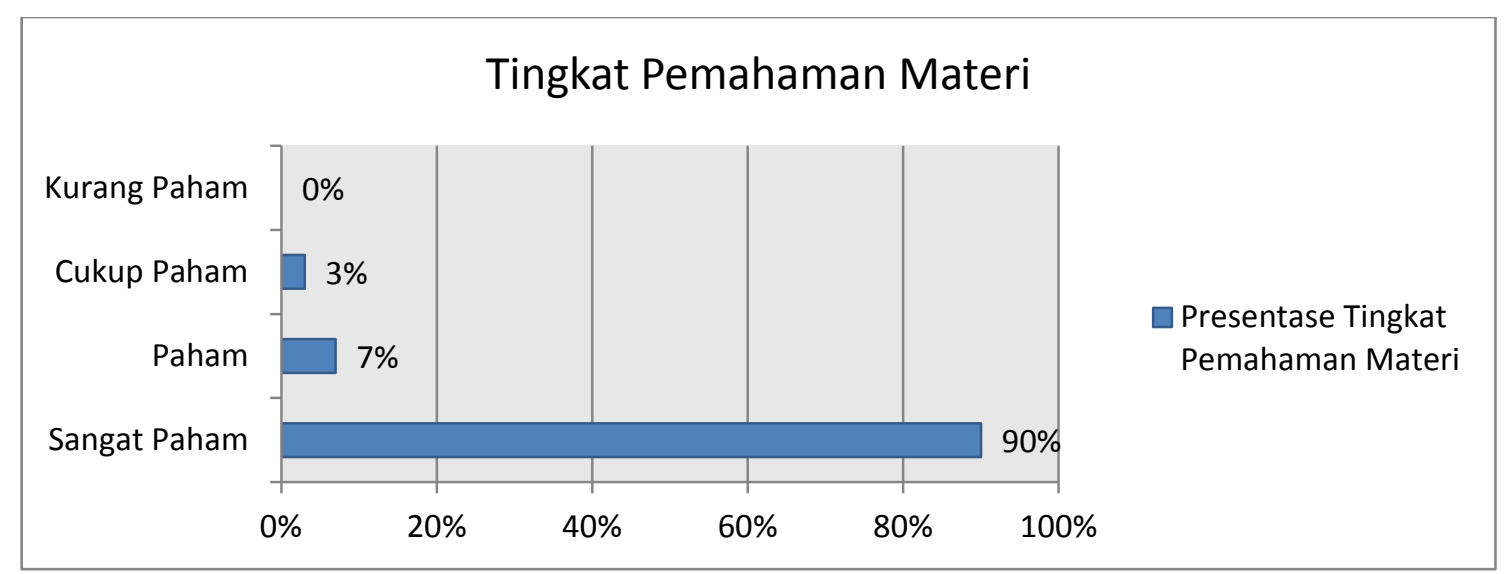

Gambar 5.

Evaluasi terhadap Tingkat Pemahaman Materi
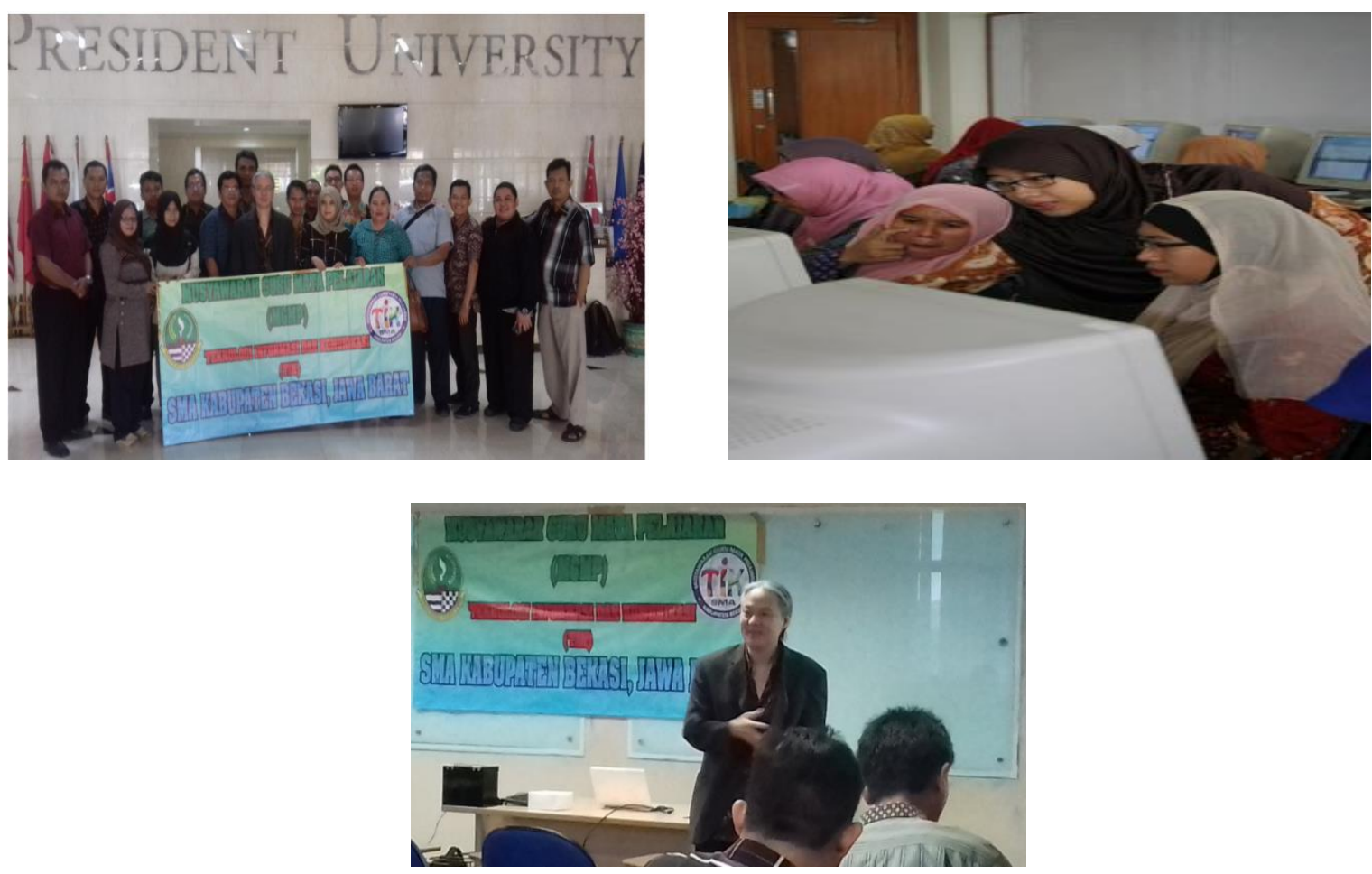

Gambar 6

Dokumentasi Pelaksanaan Kegiatan

Secara keseluruhan dapat disimpulkan kesimpulan bahwa kegiatan ini berjalan dengan lancar dan sesuai dengan rencana (dokumentasi kegiatan disajikan pada Gambar 6). Rangkaian kegiatan diawali dengan survei awal, kemudian diikuti dengan pelaksanaan dan diakhiri dengan pembuatan laporan. Berdasarkan diskusi dan interaksi yang dilakukan pleh pelaksana kegiatan dengan para peserta, dapat dilihat dan dirasakan antusiasme dan semangat yang tinggi dari para peserta. Demikian juga dari jumlah peserta yang hadir pada saat kegiatan berlangsung. Semua itu dikarenakan para peserta 
menyadari akan pentingnya proses pembelajaran secara online dalam era teknologi informasi seperti saat sekarang ini, dan hal itu bisa diaplikasikan dalam proses belajar mengajar di lingkungan sekolah masing-masing.

\section{KESIMPULAN}

Berdasarkan uraian pelaksanaan kegiatan di atas, maka dapat disimpulkan sebagai berikut:

1. Para peserta memahami dampak dari kegiatan ini, karena sebagai pendidik di era teknologi informasi seperti sekarang ini peserta merasa perlu untuk menciptakan dan mengembangkan metode pembelajaran lain di luar kelas normal, yang salah satunya melalui media pembelajaran berbasis web-blog. Melalui metode ini, cara belajar tatap muka yang biasa dilakukan secara konvensional bisa dipadukan dengan pembelajaran secara online dan akan tercipta simbiosis mutualisme. Di lain pihak, para pengajar dan para siswa juga mendapatkan pengalaman baru sehingga kegiatan belajar mengajar tercipta secara dinamis dan variatif

2. Para peserta memberikan respon yang luar biasa terkait kegiatan yang sudah dilaksanakan. Hal ini terlihat dari hasil evaluasi terhadap kualitas pemateri, kualitas modul pelatihan dan pemahaman peserta terhadap materi pelatihan.

3. Melalui kegiatan ini, para peserta merasa mendapatkan pengalaman baru dalam proses belajar mengajar mereka, sehingga diharapkan bisa memacu terciptanya kreativitas dan produktivitas segenap pihak.

\section{UCAPAN TERIMA KASIH}

Tim pelaksana kegiatan mengucapkan terima kasih kepada LRPM Universitas Presiden yang telah mendanai kegiatan pelatihan ini dalam skema pendanaan hibah internal Universitas Presiden.

\section{REFERENSI}

Aljumah, F. H. (2012). Saudi Learner Perceptions and Attitudes towards the Use of Blogs in Teaching English Writing Course for EFL Majors at Qassim University. English Language Teaching, 5(1), 100.

Goh, J.W.P., Quek, C. J., \& Lee, O. K. (2010). An Investigation of Students' Perceptions of Learning Benefits of Weblogs in an East Asian Context: A Rasch Analysis. Educational Technology \& Society, 13 (2), 90-101.

Gunawan, I. (2016). Pasaran: Menggali Nilai-nilai Permainan Tradisional dalam Mengembangkan Sifat-sifat Kepemimpinan Pendidikan. Jurnal Studi Sosial, 8(1), 5564. 
Tang, E. \& Lam C. (2014). Building an Effective Online Learning Community (OLC) In BlogBased Teaching Portfolios. Internet and Higher Education, 20 (2014) 79-85. Diunduh dari http://dx.doi.org/10.1016/ j.iheduc.2012.12.002.

Venkatesh, V., Croteau, A. M., and Rabah, M. (2014). Perceptions of Effectiveness of Instructional Uses of Technology in Higher Education in an Era of Web 2.0. 2014 47th Hawaii International Conference on System. 